\title{
PENGARUH CORPORATE GOVERNANCE, KONEKSI POLITIK DAN PROFITABILITAS TERHADAP POTENSI TAX AVOIDANCE
}

\author{
Kartika Sari ${ }^{1}$, Rawidjo Mulyo Somoprawiro ${ }^{2}$ \\ ${ }^{1}$ STIE Muhammadiyah Jakarta, kartikaseptiansari759@gmail.com \\ ${ }^{2}$ STIE Muhammadiyah Jakarta, rawidjo_ms@ymail.com
}

\begin{abstract}
ABSTRAK
Penelitian ini bertujuan untuk menganalisis dan memperoleh bukti empiris pengaruh Corporate Governance, Koneksi Politik dan Profitabilitas terhadap Tax avoidance. Variabel independen penelitian ini adalah Corporate Governance, Koneksi Politik dan Profitabilitas, variabel dependen adalah Tax avoidance dan variabel kontrol menggunakan Ukuran Perusahaan dan Umur Perusahaan. Sampel penelitian ini adalah data sekunder yang berasal dari laporan keuangan perusahaan-perusahaan manufaktur yang terdaftar di Bursa Efek Indonesia (BEI) pada tahun 2014-2018. Sampel diambil dengan metode purposive sampling dan yang memenuhi kriteria pemilihan sampel. Sampel yang digunakan sebanyak 48 perusahaan. Data diolah dengan software Eviews Versi 9 menggunakan metode Generalized Least Square (GLS). Hasil menunjukkan bahwa Koneksi Politik tidak memiliki pengaruh terhadap Tax avoidance, Corporate Governance yang diproksikan dengan Kualitas Audit tidak memiliki pengaruh terhadap Tax avoidance, sedangkan Corporate Governance yang di proksikan Komite Audit dan Dewan Komisaris Independen berpengaruh positif terhadap Tax avoidance. Profitabilitas berpengaruh negatif terhadap Tax avoidance.
\end{abstract}

Kata Kunci: Corporate Governance, Koneksi Politik, Profitabilitas, Ukuran Perusahaan, Umur Perusahaan, Tax avoidance

\begin{abstract}
This study aims to analyze and obtain empirical evidence of Corporate Governance, Political Connection and Profitability to Tax avoidance. Independent variabels are proxied by Corporate Governance, Political Connection and Profitability, the dependent variable is proxied by Tax avoidance and control variables are proxied by Firm Size and Firm Age. The sample used in this study is secondary data derivied from the financial statements of manufacturing companies listed on the Indonesia Stock Exchange (IDX) in 2014-2018. Sample were taken by purposive sampling method and met the sample selection criteria. The sample used was 48 companies. Data is processed with Eviews Version 9 software and using the Generalized Least Square (GLS) method. The results show that Political Connections do not have an influence on Tax Avoidance, Corporate Governance that is proxied by Audit Quality does not have an effect on Tax Avoidance, while Corporate Governance which is proxied by the Audit Committee and Independent Board of Commissioners has a positive effect on Tax Avoidance. Profitability has negative effect to Tax avoidance.
\end{abstract}

Keywords: Corporate Governance, Political Connection, Profitability, Firm Size, Firm Age, Tax avoidance

Naskah diterima: 11-03-2020, Naskah dipublikasikan: 30-04-2020

\section{PENDAHULUAN}

Tax avoidance dilakukan oleh Wajib Pajak dengan memanfaatkan celah atau loopholes dari peraturan yang ada untuk mengurangi bahkan menghilangkan kewajiban dalam perpajakan. Tax avoidance merupakan salah satu strategi dalam perencanaan pajak (tax planning). Zain 
(2008:66) menjelaskan bahwa tax planning sebagai proses mengorganisasi usaha wajib pajak sedemikian rupa sehingga utang pajaknya, baik pajak penghasilan maupun pajak-pajak lainnya, berada dalam posisi yang paling minimal, sepanjang hal ini dimungkinkan baik oleh ketentuan peraturan perundang-undangan perpajakan maupun secara komersial.

Tax planning merujuk pada proses merekayasa usaha dan transaksi Wajib Pajak supaya utang pajak berada dalam jumlah yang minimal tetapi masih dalam bingkai peraturan perpajakan. Dyreng et al., (2009) menyatakan perusahaan yang melakukan tax avoidance tidak selalu salah karena ada banyak ketentuan dalam pajak yang mendorong perusahaan untuk mengurangi pajak, ditambah dengan adanya batasan hukum yang tidak jelas khususnya untuk transaksi yang bersifat kompleks. Meskipun tax avoidance dianggap sebagai sebuah tindakan legal atau masih dalam ranah hukum yang berlaku. Namun, bila kita telik dari segi moral, hal tersebut menunjukkan rendahnya kesadaran wajib pajak dalam melaksanakan kewajiban atas pajak yang dibayarkan.

Berkaitan dengan pengindaran pajak diatas, secara umum terdapat dua jenis perlawanan yang sering di lakukan oleh wajib pajak atau masyarakat yang dapat menghambat dalam upaya pemungutan pajak (Mardiasmo, 2011). Jenis perlawanan yang pertama adalah perlawanan pasif, yaitu perlawanan yang disebabkan oleh beberapa hal, antara lain karena perkembangan intelektual dan moral masyarakat, rumitnya sistem perpajakan untuk dipahami dan dijalankan, kurangnya sistem kontrol dan pelaksanan pemungutan pajak. Jenis perlawanan yang kedua adalah perlawanan aktif yaitu semua usaha yang dilakukan oleh wajib pajak untuk menghindari pajak, baik yang bersifat Legal (tax avoidance) maupun yang bersifat ilegal/melanggar undangundang (tax evasion). Apapun bentuk perlawanan yang dilakukan oleh wajib pajak tentu saja akan berimbas pada terhambatnya upaya pemungutanpajak yang akhirnya berujung pada tidak maksimalnya jumlah pajak yang bisa dikumpulkan (Arviyanti dan Muiz, 2018)

Fenomena tax avoidance di Indonesia dapat dilihat dari rasio pajak (tax ratio). Tax ratio adalah perbandingan atau persentase penerimaan pajak terhadap Produk Domestik Bruto (PDB). PDB adalah total nilai barang dan jasa yang dihasilkan oleh perekonomian suatu negara, dikurangi nilai barang dan jasa yang digunakan dalam produksi. Angka tax ratio merupakan salah satu indikator yang digunakan untuk menilai kinerja penerimaan pajak. Saat ini tax ratio di Indonesia masih tergolong rendah jika dibandingkan dengan tax ratio di negara-negara maju. Diolah dari data yang dirilis World Bank, IMF dan OECD tahun 2018, negara-negara maju memiliki tax revenue to GDP ratio yang tinggi seperti Amerika Serikat di level $26 \%$, Inggris 30,6 \%, Jerman $37 \%$, dan negara-negara skandinavia dengan rasio di atas $40 \%$. Sementara di wilayah ASEAN tax ratio Indonesia masih lebih rendah dibandingkan Malaysia 14,4 perse\%, Filipina 13,67 \%, Singapura 14,29 \%, dan Kamboja 15,3 \%. Menurut Berita Resmi BPS nomor 16 tanggal 5 Februari 2018 sejak tahun 2015 hingga 2017, tax ratio Indonesia hanya berkutat di angka $10 \%$ di mana tax ratio tahun 2017 berada di level 10,8 \% dan pertumbuhan ekonomi 5,07 \% Terlebih di tahun 2018, tax ratio hanya ditarget sebesar 10,9 \%. Jika kebutuhan belanja sekitar 15-16 \% dari total PDB, idealnya tax ratio harus mendekati angka tersebut untuk mendorong fiscal sustainability dan menjamin defisit tetap terkendali (MHD. Ricky .K.L., 2018)

Beberapa penelitian sebelumnya mencoba mengaitkan Corporate Governance terhadap Tax avoidance dan didapatkan hasil penelitian yang berbeda. Menurut Watkins et al. (2004) kualitas audit adalah kemungkinan dimana auditor akan menemukan salah saji material dalam laporan keuangan klien. Audit yang dilaksanakan auditor dikatakan berkualitas, jika memenuhi ketentuan atau standar pengauditan berdasarkan Standar Profesional Akuntan Publik (SPAP). Maharani dan Suardana (2014), Rahmi Fadhilah (2014) menguji kualitas audit terhadap tax avoidance yang hasilnya membuktikan bahwa kualitas audit berpengaruh negatif terhadap tax avoidance, Dewi dan Jati (2014) menemukan bahwa kualitas audit berpengaruh positif terhadap tax avoidance, sedangkan Winata (2015) menemukan bahwa kualitas audit tidak berpengaruh signifikan terhadap tax avoidance.

Komite audit adalah komite yang dibentuk oleh dan bertanggung jawab kepada dewan komisaris dalam membantu melaksanakan tugas dan fungsi dewan komisaris (Peraturan OJK 
55/2015). Terbentuknya komite audit pada perusahaan-perusahaan di banyak negara merupakan ciri dari corporate governance yang mulai terbentuk dengan baik. Fadhilah (2014) menguji pengaruh komite audit terhadap tax avoidance, dan hasilnya menyatakan bahwa komite audit berpengaruh positif terhadap tax avoidance, sedangkan Maharani dan Suardana (2014), Dewi dan Jati (2014) menemukan bahwa komite audit berpengaruh negatif terhadap tax avoidance. Hal ini berbeda dengan hasil penelitian yang dilakukan oleh Sari (2010), Swingly dan Sukartha (2015) yang menemukan bahwa komite audit tidak berpengaruh terhadap tax avoidance.

Komisaris bertugas untuk melakukan pengawasan dan memberikan nasihat kepada direktur perseroan, di Indonesia komisaris ditunjuk oleh RUPS. Keberadaan komisaris mempunyai pengaruh terhadap kualitas laporan keuangan dan dipakai sebagai ukuran tingkat rekayasa yang dilakukan oleh manajer (Chtourou et al. 2001). Sari (2010), Maharani dan Suardana (2014) melakukan penelitian mengenai pengaruh dewan komisaris independen terhadap tax avoidance yang hasilnya membuktikan bahwa dewan komisaris independen berpengaruh negatif terhadap tax avoidance. Hal ini bertentangan dengan penelitian yang dilakukan oleh Fadhilah (2014), Agusti (2014) yang menemukan bahwa dewan komisaris independen tidak berpengaruh terhadap tax avoidance.

Selain corporate governance, faktor lain yang berpengaruh terhadap tax avoidance adalah koneksi politik. Disatu sisi, koneksi politik bernilai bagi perusahaan. Wati et al. (2016), Wati (2017), Maulana dan Wati (2019) memberikan bukti empiris bahwa koneksi politik mampu meningkatkan nilai perusahaan, namun disisi lain, koneksi politik di perusahaan juga dapat berdampak terhadap tax avoidance Hal ini dibuktikan dengan penelitian Mulyani dkk, (2014) dan Prastiwi (2016), Munawaroh \& Ramdany (2019) yang menemukan bahwa hubungan politik berpengaruh positif terhadap tax avoidance. Sedangkan Utari dan Supadmi (2017), Lugesti (2017), Aminah, dkk (2018), Butje dan Tjondro (2014), menemukan bahwa koneksi politik berpengaruh negatif terhadap tax avoidance.

Faccio (2006) menyatakan sebuah perusahaan dikatakan memiliki hubungan politik jika paling kurang satu pemegang saham utama (orang yang memiliki setidaknya 10 persen hak suara berdasarkan jumlah saham yang dimiliki) atau satu dari pimpinan (CEO, presiden direktur, wakil presiden direktur, kepala bagian atau sekretaris) merupakan anggota parlemen, menteri, atau memiliki hubungan dekat dengan tokoh atau partai politik. Perusahaan dengan hubungan politik mampu melakukan tax planning yang lebih agresif karena adanya perlindungan dari pemerintah yang berdampak pada menurunnya transparansi laporan keuangan. Namun hasil ini berbeda dengan penelitian yang dilakukan oleh Marfu'ah (2015), Murniyana (2018), Dharma dan Ardiana (2016), dan Lestari dan Putri (2017) yang menyatakan bahwa koneksi politik tidak berpengaruh terhadap tax avoidance.

Faktor selanjutnya yang turut mempengaruhi tindakan tax avoidance adalah profitabilitas. Profitabilitas merupakan salah satu pengukur untuk menilai kinerja suatu perusahaan. Profitabilitas terdiri dari beberapa rasio diantaranya adalah return on assets (ROA). ROA merupakan satu indikator yang mencerminkan performa keuangan perusahaan, semakin tinggi nilai ROA, maka akan semakin bagus performa perusahaan. ROA berguna untuk mengukur sejauh mana efektivitas perusahaan dalam memanfaatkan seluruh sumber daya yang dimilikinya. Kurniasih dan Sari (2013), Dewinta dan Setiawan (2016), Fadila dan Rusli (2016) melakukan pengujian pengaruh ROA terhadap tax avoidance dan hasilnya menunjukkan bahwa ROA berpengaruh positif terhadap tax avoidance. Maharani dan Suardana (2014) dan Agusti (2014) menjelaskan bahwa ROA berpengaruh negatif terhadap tax avoidance. Sedangkan Marfu'ah (2015) menemukan bahwa ROA tidak berpengaruh terhadap tax avoidance.

Berdasarkan latar belakang tersebut, penelitian-penelitian terdahulu masih menghasilkan banyak perbedaan, maka perlu dilakukan penelitian kembali tentang pengaruh Corporate Governance, koneksi politik dan profitabilitas terhadap tax avoidance di Indonesia. Penelitian ini bertujuan untuk menguji dan menemukan bukti secara empiris mengenai pengaruh Corporate Governance, koneksi politik dan profitabilitas terhadap tax avoidance secara komprehensif. 


\section{KAJIAN LITERATUR \\ Teori Agensi}

Menurut Scott (2000), teori keagenan adalah pendesainan kontrak yang tepat untuk menyelaraskan kepentingan prinsipal dan agen dalam hal terjadi konflik kepentingan. Hubungan keagenan sebagai suatu kontrak dimana satu atau lebih orang (prinsipal) memerintah orang lain (agen) membuat keputusan yang terbaik bagi prinsipal. Prinsipal mendelegasikan tanggung jawab pengambilan keputusan kepada agen dimana hak dan kewajiban kedua belah pihak diuraikan dalam suatu perjanjian kerja yang saling menguntungkan. Agen diasumsikan menerima kepuasan tidak hanya dari kompensasi finansial tetapi juga dari keuntungankeuntungan lain yang diperoleh dari hubungan agensi. Keuntungan tersebut dapat berupa waku luang, kondisi pekerjaan yang atraktif, fleksibilitas jam kerja, dan lain-lain. Dalam kondisi ini agen dikatakan mempunyai sikap opportunistic. Pada teori agensi yang disebut principal adalah pemegang saham dan agent adalah manajemen yang mengelola perusahaan. Pemegang saham berharap agent akan bertindak atas kepentingannya atas wewenang yang telah diberikannya. Tetapi seringkali agent tidak selalu bertindak demi kepentingan pemegang saham atau melakukan tindakan yang bertentangan dengan keinginan pemegang saham sehingga terjadi konflik antara agent dengan pemegang sahamnya.

\section{Tax avoidance}

Tax avoidance adalah suatu skema transaksi yang ditujukan untuk meminimalkan beban pajak dengan memanfaatkan kelemahan-kelemahan ketentuan perpajakan suatu negara. Lim (2011) mendefinisikan tax avoidance sebagai penghematan pajak yang timbul dengan memanfaatkan ketentuan perpajakan yang dilakukan secara legal untuk meminimalkan kewajiban pajak.

Menurut Hanlon dan Heitzman (2010) pengukuran tax avoidance menggunakan ETR (Effective Tax Rate) adalah sebagai berikut :

Worldwide cash tax paid

Worldwide total pre-tax accounting income

$$
\text { ETR }=\frac{\text { Atau }}{\text { Laba Sebelum Pajak }}
$$

\section{Corporate Governance}

Corporate governance merupakan tata kelola perusahaan yang menjelaskan hubungan antara berbagai partisipan dalam perusahaan yang menentukan arah kinerja perusahaan (Haruman, 2008). Corporate governance muncul untuk memberikan keyakinan dan kepercayaan terhadap investor bahwa dana yang mereka investasikan dalam perusahaan digunakan secara tepat dan efisien serta tujuan perusahan dapat tercapai yaitu meningkatkan kekayaan pemegang saham dan nilai perusahaan juga meningkat. Proksi dari corporate governance yang digunakan dalam penelitian ini adalah kualitas audit, komite audit dan dewan komisaris independen.

\section{Kualitas Audit}

Kualitas audit merupakan konsep yang menunjukkan bahwa auditor dapat melaksanakan tugas secara profesional berdasarkan etika profesi, kompetensi dan independensi.Ukuran KAP (Kantor Akuntan Publik) BIG 4 merupakan salah satu indikator dari kualitas audit yang tinggi. Untuk mengukur kualitas audit dalam penelitian ini digunakan variabel dummy yaitu diberi skor 1 jika diaudit oleh KAP yang berafiliasi BIG 4, dan diberi skor 0 jika lainnya (Herusetya, 2009). 


\section{Komite Audit}

Sebagai pihak yang diberi otoritas oleh dewan komisaris, komite audit bertugas untuk mengawasi proses pelaporan keuangan dalam perusahaan, sehingga keberadaan komite audit dalam perusahaan akan memperkecil kemungkinan terjadinya manajemen laba. Keberadaan Komite Audit diatur melalui Surat Edaran Bapepam Nomor: SE/03 PM/2002 (bagi perusahaan publik) dan keputusan Menteri BUMN Nomor: Kep-103/MBU/2002 (Bagi BUMN) Komite Audit sedikitnya terdiri dari tiga orang, diketuai oleh seorang Komisaris Independen perusahaan dengan dua orang eksternal yang independen serta menguasai dan memiliki latar belakang akuntansi dan keuangan.

Angruningrum dan Wirakusuma (2013) melakukan pengukuran komite audit dengan menggunakan rumus sebagai berikut :

Jumlah komite audit yang memiliki latar belakang akuntansi atau keuangan

$$
\text { Jumlah total komite audit }
$$

\section{Dewan Komisaris Independen}

Komposisi dewan komisaris harus sedemikian rupa sehingga memungkinkan pengambilan keputusan yang efektif, tepat dan cepatserta dapat bertindak secara independen dalam arti tidak mempunyai kepentingan yang dapat mengganggu kemampuannya untuk melaksanakan tugasnya secara mandiri dan kritis dalam hubungan satu sama lain dan terhadap direksi (Triwahyuningtias, 2012). Pengukuran dewan komisaris independen dalam penelitian ini (Wardhani, 2006):

$$
\text { Jumlah Dewan Komisaris Independen Pada Periode t }
$$

Total Dewan Komisaris Pada Periode t

\section{Koneksi Politik}

Faccio (2006) menyatakan sebuah perusahaan dikatakan memiliki koneksi politik jika paling kurang satu saham utama (orang yang memiliki setidaknya 10 persen hak suara berdasarkan jumlah saham yang dimiliki) atau satu dari pimpinan (CEO, presiden direktur, wakil presiden direktur, kepala bagian atau sekretaris) merupakan anggota parlemen, menteri, atau memiliki hubungan dekat dengan tokoh atau partai politik.

Pengukuran koneksi politik menggunakan variabel dummy yaitu diberi skor 1 untuk perusahaan yang mempunyai koneksi politik dan 0 jika sebaliknya (Wati et al., 2019).

\section{Profitabilitas}

Profitabilitas merupakan suatu indikator kinerja yang dilakukan manajemen dalam mengelola kekayaan perusahaan yang ditunjukkan oleh laba yang dihasilkan. Secara garis besar, laba yang dihasilkan perusahaan berasal dari penjualan dan investasi yang dilakukan oleh perusahaan (Sudarmadji dan Sularto, 2007). Rasio profitabilitas mengukur kemampuan perusahaan dalam menghasilkan keuntungan dari kegiatan bisnis yang dilakukan. Proksi dari rasio profitabilitas yang digunakan dalam penelitian ini adalah menggunakan return on assets (ROA). ROA mengukur seberapa efektif perusahaan dapat mengubah pendapatan dari pengembalian investasinya menjadi aset. Semakin tinggi ROA perusahaan, maka semakin baik kinerja perusahaan. Untuk menghitung ROA menggunakan rumus (Permata dkk., 2018)

ROA = Laba Bersih / Total Aset

\section{Variabel Kontrol \\ Ukuran Perusahaan}

Tahap kedewasaan perusahaan ditentukan berdasarkan total aktiva, semakin besar total aktiva menunjukkan bahwa perusahaan memiliki prospek baik dalam jangka waktu yang relatif 
panjang (Kurniasih dan Sari, 2013). Indikator yang digunakan untuk mengukur tingkat ukuran perusahaan adalah total aset karena ukuran perusahaan diproksi dengan Ln total assets. Penggunaan natural $\log (\mathrm{Ln})$ dalam penelitian ini dimaksudkan untuk mengurangi fluktuasi data yang berlebihan tanpa mengubah proporsi dari nilai asal yang sebenarnya (Fadila dan Rusli, 2017).

\section{Umur Perusahaan}

Umur perusahaan adalah lamanya perusahaan berdiri. Seiring waktu perusahaan belajar untuk semakin baik dan lebih efisien serta memiliki keunggulan kompetitif dalam inti bisnisnya dan mendorong keberhasilan dan kemakmuran bagi perusahaan. Loderer dan Waelchli (2010) menjelaskan bahwa seiring dengan berjalannya waktu, perusahaan akan menjadi tidak efisien. Perusahaan yang mengalami penuaan harus mengurangi biaya termasuk biaya pajaknya akibat pengalaman dan pembelajaran yang dimiliki serta pengaruh perusahaan lain baik dalam industri yang sama maupun berbeda.Umur perusahaan dalam penelitian ini menggunakan umur perusahaan dari tanggal berdirinya perusahaan tersebut (Hariyanto dan Juniarti, 2014).

\section{Pengembangan Hipotesis}

Kualitas audit merupakan konsep yang menunjukkan bahwa auditor dapat melaksanakan tugas secara profesional berdasarkan etika profesi, kompetensi dan independensi. Kualitas audit dapat diartikan sebagai bagus tidaknya suatu pemeriksaan yang telah dilakukan oleh auditor. Ukuran KAP (Kantor Akuntan Publik) BIG 4 merupakan salah satu indikator dari kualitas audit yang tinggi. Semakin tinggi kualitas audit akan meminimalisir adanya praktik penghindaran pajak pada suatu perusahaan.Fadhilah (2014), Maharani dan Suardana (2014) menemukan bahwa kualitas audit berpengaruh negatif terhadap tax avoidance.

Berdasarkan uraian tersebut, hipotesis yang dapat dikembangkan adalah :

\section{H1a : Kualitas Audit berpengaruh negatif terhadap Tax avoidance.}

Terbentuknya komite audit pada perusahaan-perusahaan di banyak negara merupakan ciri dari corporate governance yang mulai terbentuk dengan baik. Keberadaan komite audit merupakan suatu persyaratan untuk listed di NYSE (New York Stocks Exchange) sejak akhir 1970 dan menjadi ketentuan hukum di Kanada sejak pertengahan 1970 (Komite Nasional Good Corporate Governance, 2002). Komite audit dengan keahlian akuntansi atau keuangan berpengaruh terhadap keputusan yang diambil perusahaan, sehingga membantu mengontrol manajer agar berlaku sesuai kepentingan pemegang saham. Jumlah komite audit yang semakin banyak pada suatu perusahaan dapat meminimalkan praktek tax avoidance yang dilakukan perusahaan.Maharani dan Suardana (2014), Dewi dan Jati (2014), Winata (2014) membuktikan bahwa komite audit berpengaruh negatif terhadap tax avoidance.

Berdasarkan uraian tersebut, hipotesis yang dapat dikembangkan adalah :

\section{H1b : Komite Audit berpengaruh negatif terhadap Tax avoidance.}

Suatu perusahaan dapat dikatakan good corporate governance jika salah satunya yaitu komisaris melakukan pengawasan sesuai dengan aturan-aturan yang ada. Komisaris independen setidaknya mempunyai fungsi pengawasan dan fungsi penasihat sebagaimana yang tertera pada Undang-Undang Perseroan Terbatas. Komposisi dewan komisaris harus sedemikian rupa sehingga memungkinkan pengambilan keputusan yang efektif, tepat dan cepat serta dapat bertindak secara independen dalam arti tidak mempunyai kepentingan yang dapat mengganggu kemampuannya untuk melaksanakan tugasnya secara mandiri dan kritis dalam hubungan satu sama lain dan terhadap direksi (Triwahyuningtias, 2012). Semakin besar komposisi dewan komisaris independen akan meningkatkan pengawasan dan pengendalian pada suatu perusahaan, sehingga perusahaan akan terhindar dari perilaku penghindaran pajak. Sari (2010), Maharani dan Suardana (2014), Winata (2014) membuktikan bahwa dewan komisaris independen berpengaruh negatif terhadap tax avoidance. 
Berdasarkan uraian tersebut, hipotesis yang dapat dikembangkan adalah :

H1c: Dewan Komisaris Independen berpengaruh negatif terhadap Tax avoidance

Perusahaan berkoneksi politik adalah perusahaan yang dengan cara-cara tertentu mempunyai ikatan secara politik atau mengusahakan adanya kedekatan dengan politisi atau pemerintah. Perusahaan yang memiliki hubungan dengan politisi atau pemerintah akan memperoleh keuntungan dan manfaat strategis dari adanya kedekatan tersebut. Bahkan perusahaan akan mendapatkan keuntungan khususnya dalam hal pengurangan biaya kompetisi, mengurangi kewajiban peraturan atau lebih mudah dalam mendapatkan kontrak yang berhubungan dengan proyek pemerintah (Goldman et al., 2009). Perusahaan yang terkoneksi politik akan memungkinkan adanya potensi tax avoidance,karena memiliki hubungan kedekatan dengan politisi atau pemerintah. Utari dan Supadmi (2017), Lugesti (2017), Aminah dkk. (2018), Butje dan Tjondro (2014) menemukan bahwa koneksi politik berpengaruh positif terhadap tax avoidance.

Berdasarkan uraian tersebut, hipotesis yang dapat dikembangkan adalah :

H2 : Koneksi Politik berpengaruh positif terhadap Tax avoidance.

Rasio profitabilitas dapat digunakan untuk mengetahui kemampuan perusahaan menghasilkan laba dari pendapatan terkait penjualan, aset, dan ekuitas berdasarkan dasar pengukuran tertentu. Rasio profitabilitas diperlukan untuk memberikan informasi keuangan kepada pihak-pihak yang berkepentingan seperti investor, kreditur, debitur, dll. Pengukuran profitabilitas dalam penelitian ini menggunakan proksi return on assets (ROA). Return on assets ratio (ROA) digunakan untuk menilai persentase keuntungan dan kemampuan manajemen perusahaan dalam memperoleh laba dengan memanfaatkan keseluruhan total aset yang dimiliki.

Perusahaan yang dapat mengelola asetnya dengan baik akan berpotensi melakukan penghindaran pajak karena perusahaan akan mendapatkan keuntungan dari insentif pajak dan kelonggaran pajak lainnya. Darmawan dan Sukartha (2014), Dewinta dan Setiawan (2016), Kurniasih dan Sari (2013), Fadila dan Rusli (2016), dan Waluyo dkk. (2015) menemukan bahwa [rofitabilitas berpengaruh positif terhadap tax avoidance.

Berdasarkan uraian tersebut, hipotesis yang dapat dikembangkan adalah :

H3 : Profitabilitas berpengaruh positif terhadap Tax avoidance.

\section{KERANGKA PIKIR}

Berdasarkan uraian di atas, dapat dibuat suatu kerangka pemikiran teoritis yang menggambarkan variabel-variabel yang mempengaruhi penghindaran pajak yaitu:

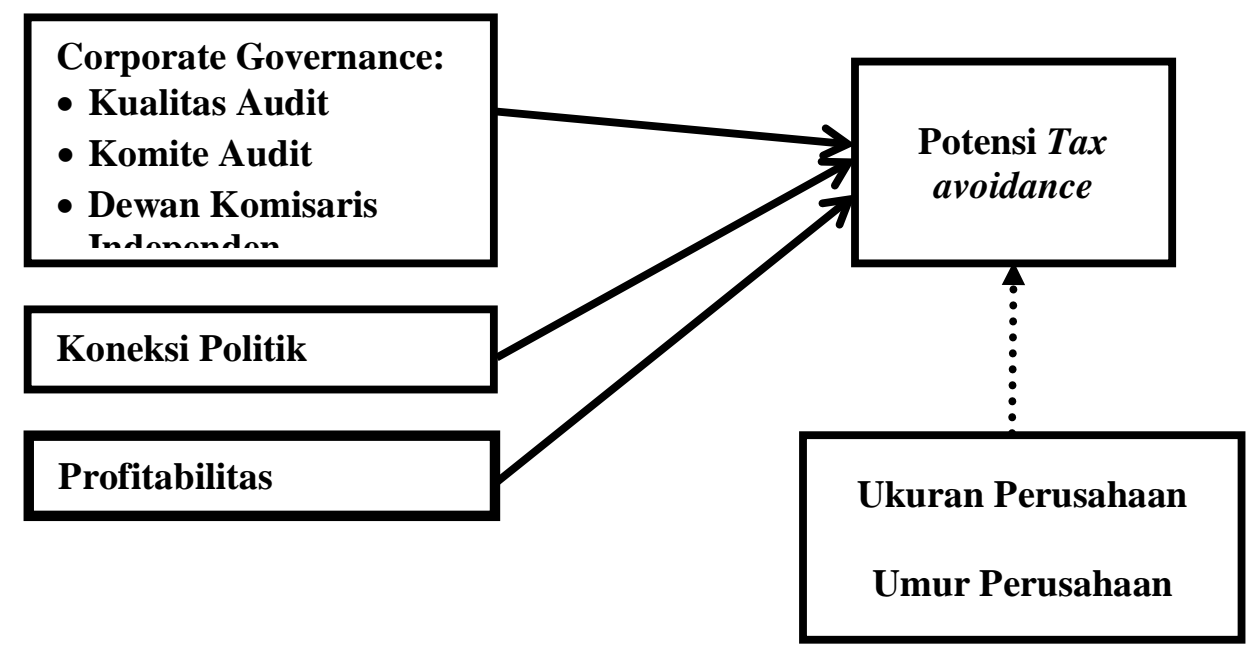

Gambar 1. Kerangka Pikir 


\section{METODE PENELITIAN}

Penelitian dilakukan pada bulan Maret 2019 hingga Juli 2019, dengan mengumpulkan data mengenai laporan keuangan perusahaan yang terdaftar pada BEI di www.idx.co.id dari tahun 2014 sampai dengan 2018.

Tabel 1 . Pengambilan Sampel

\begin{tabular}{|l|c|}
\hline \multicolumn{1}{|c|}{ Kriteria } & Jumlah \\
\hline Perusahaan manufaktur yang terdaftar di BEI & 162 \\
\hline Perusahaan dengan annual report tidak lengkap & $(59)$ \\
\hline Perusahaan yang menggunakan mata uang selain rupiah & $(22)$ \\
\hline Perusahaan dengan nilai laba negative & $(31)$ \\
\hline Perusahaan yang memiliki nilai ETR $>1$ & $(2)$ \\
\hline Jumlah Sampel Menyeluruh & 48 \\
\hline
\end{tabular}

Sumber : Data diolah, 2019

Dalam penelitian ini dapat dibentuk persamaan :

Model Penelitian :

$\mathrm{PTA}=\alpha_{0}+\beta_{1} \mathrm{KA}+\beta_{2} \mathrm{KT}+\beta_{3} \mathrm{DKI}+\beta_{4} \mathrm{KP}+\beta_{5} \mathrm{ROA}+\beta_{6}$ SIZE $+\beta_{7}$ AGEe

Dimana :

$\alpha \quad$ : Konstanta

$\beta \quad$ : Koefisien Regresi

KA : Kualitas Audit

KT : Komite Audit

DKI : Dewan Komisaris Independen

KP : Koneksi Politik

ROA : Return On Assets

SIZE : Ukuran Perusahaan

AGE : Umur Perusahaan

PTA : Potensi Tax avoidance

e : Error

Dasar pengujian hipotesis menggunakan perbandingan ttabel dengan tsatistik atau pvalue (Wati, 2017). Jika P-value < 0,05 maka hipotesis penelitian diterima.

\section{ANALISIS DATA DAN PEMBAHASAN}

Tabel 2. Deskripsi Variabel Penelitian

\begin{tabular}{|l|l|l|l|l|l|}
\hline \multicolumn{1}{|c|}{ Variabel } & \multicolumn{1}{c|}{ N } & \multicolumn{1}{c|}{ Min } & \multicolumn{1}{c|}{ Max } & \multicolumn{1}{c|}{ Mean } & \multicolumn{1}{c|}{ St. Dev } \\
\hline KA & 240 & 0 & 1 & 0.520833 & 0.50061 \\
\hline KT & 240 & 0.25 & 1 & 0.852292 & 0.209986 \\
\hline DKI & 240 & 0.272727 & 0.8 & 0.409254 & 0.104436 \\
\hline KP & 240 & 0 & 1 & 0.425 & 0.495376 \\
\hline ROA & 240 & 0.000282 & 0.526704 & 0.093090879 & 0.090308864 \\
\hline TA & 240 & 0.02914 & 0.971144 & 0.292271 & 0.142235 \\
\hline
\end{tabular}

Sumber: Data diolah, 2019

Berdasarkan hasil perhitungan statistik deskritif variabel Tax avoidance (TA) nilai maksimum sebesar 0.971144 , nilai rata-rata sebesar 0.292271 , dan nilai standard deviasinya sebesar 0.142235. Nilai rata-rata Tax avoidance (TA) sebesar 29,23 \%, hal ini menunjukkan 
bahwa adanya praktik penghindaran pajak yang terjadi pada perusahaan sampel walaupun cenderung rendah. Variabel Kualitas Audit (KA) menggunakan variabel dummy yang nilainya hanya 1 atau 0, sehingga nilai minimum Kualitas Audit (KA) sebesar 0 dan maksimum sebesar 1. Perusahaan yang di audit oleh Kantor Akuntan Publik (KAP) Big 4 adalah sebesar 52,08 \% dan sisanya 47,92 \% di audit oleh KAP selain Big 4. Sementara nilai standard deviasi untuk Kualitas Audit (KA) sebesar 0.50061. Variabel nilai minimum Komite Audit (KT) adalah 0 dan nilai maksimumnya 1 dengan nilai rata-rata sebesar 0.852292 , serta standard deviasinya sebesar 0.209986. Nilai rata-rata Komite Audit (KT) sebesar 85,23 \% menunjukkan bahwasebagian besar perusahaan sampel memiliki anggota komite audit yang latar belakangnya akuntansi atau keuangan. Variabel Dewan Komisaris Independen (DKI) memiliki nilai minimum sebesar 0.272727, nilai maksimum sebesar 0.8 , nilai rata-rata sebesar 0.409254 serta nilai standard deviasinya sebesar 0.104436. Dapat dilihat jika nilai rata-rata dewan komisaris independen pada perusahaan sampel sebesar 40,93 \% dimana jumlah tersebut sesuai dengan peraturan BEI, bahwa untuk perusahaan yang terdaftar di BEI harus mempunyai jumlah komisaris independen 30 \% dari seluruh anggota dewan komisaris. Variabel Koneksi Politik (KP) menggunakan variabel dummy yang nilainya hanya 1 atau 0, sehingga nilai minimum untuk Koneksi Politik (KP) adalah 0 dan nilai maksimumnya adalah 1. Nilai rata-rata Koneksi Politik (KP) sebesar 0.425, hal ini menunjukkan bahwa 42,5 \% perusahaan sampel terkoneksi politik. Nilai standard deviasinya sebesar 0.495376 . Variabel Profitabilitas terlihat bahwa nilai minimum yang diukur dengan Return on Assets (ROA) sebesar 0.000282, nilai maksimumnya sebesar 0.526704, nilai rata-rata sebesar 0.093090879 dan nilai standard deviasinya sebesar 0.090308864 . Dengan nilai rata-rata Profitabilitas (ROA) sebesar 9,31 \% hal ini berarti bahwa rata-rata perusahaan sampel memiliki kemampuan untuk menghasilkan laba bersih dari jumlah total aktivanya sebesar 9.31\%.

Tabel 3. Hasil Regresi Random Effect Model

\begin{tabular}{ccccc}
\hline Variabel & Coefficient & Std. Error & t-Statistic & Prob. \\
\hline \hline C & -0.651628 & 0.14214 & -4.58442 & 0.0000 \\
KA & -0.000343 & 0.028916 & -0.01188 & 0.9905 \\
KT & 0.262423 & 0.080042 & 3.278557 & 0.0012 \\
DKI & 0.284326 & 0.117309 & 2.423741 & 0.0161 \\
KP & 0.031103 & 0.029454 & 1.055977 & 0.2921 \\
ROA & -0.206975 & 0.021777 & -9.50427 & 0.0000 \\
AGE & 0.000328 & 0.00075 & 0.437858 & 0.6619 \\
SIZE & -0.00495 & 0.008836 & -0.56018 & 0.5759 \\
\hline
\end{tabular}

Sumber: Eviews, data diolah, 2019

Berdasarkan nilai probabilitas Kualitas Audit (KA) sebesar 0.9905> 0.05 dan coefficientnya sebesar -0.000343 artinya bahwa kualitas audit tidak berpengaruh negatif terhadap tax avoidance. Tanda negatif pada koefisien menggambarkan adanya hubungan yang negatif antara kualitas audit terhadap tax avoidance. Hasil penelitian ini mengindikasikan jika tidak ada perbedaan antara perusahaan yang diaudit oleh KAP Big4 maupun perusahaan yang diaudit oleh KAP non Big 4 terhadap penanggulangan tindakan penghindaran pajak, hal ini karena KAP yang melakukan audit laporan keuangan pada suatu perusahaan berpedoman pada DSPAP IAPI (Dewan Standar Profesional Akuntan Publik Institut Akuntan Publik Indonesia). Beberapa KAP non BIG 4 belakangan ini telah berkembang cukup pesat dan banyak dipertimbangkan oleh perusahaan sebagai auditor mereka dan kualitas audit yang dihasilkan tidak jauh berbeda. Auditor yang bekerja pada KAP non Big 4 dapat mempertahankan sikap independen dan profesionalnya dengan melandaskan pekerjaan mereka pada standar atau 
peraturan yang berlaku juga kode etik akuntan publik, sehingga dapat memberikan hasil audit yang berkualitas. Hasil pengujian ini sejalan dengan penelitian yang dilakukan oleh Winata (2014), Damayanti dan Susanto (2015) dan Saputra dkk. (2015) yang menunjukkan tidak adanya pengaruh kualitas audit terhadap tax avoidance.

Nilai probabilitas Komite Audit (KT) sebesar $0.0012<0.05$ dan coefficientnya sebesar 0.262423 artinya bahwa komite audit berpengaruh positif terhadap tax avoidance. Tanda positif pada koefisien menggambarkan adanya korelasi yang positif antara komite audit terhadap tax avoidance. Hasil penelitian ini menunjukkan bahwa adanya komite audit yang memiliki latar belakang akuntansi atau keuangan pada suatu perusahaan berpengaruh terhadap praktik tax avoidance. Hal ini dikarenakan anggota komite audit pada suatu perusahaan tidak menjalankan fungsinya dengan baik untuk meningkatkan integritas dan kredibilitas pelaporan keuangan perusahaan. Hasil pengujian ini mendukung penelitian yang dilakukan oleh Annisa dan Kurniasih (2012), Fadhilah (2014) dan Tandean (2015) yang menemukan adanya pengaruh positif komite audit terhadap perilaku penghindaran pajak.

Nilai probabilitas Dewan Komisaris Independen (DKI) sebesar $0.0161<0.05$ dan coefficientnya sebesar 0.284326 artinya bahwa dewan komisaris independen berpengaruh positif terhadap tax avoidance. Tanda positif pada koefisien menggambarkan adanya hubungan yang positif antara komite audit terhadap tax avoidance, dengan nilai probabilitas $<0.05$ menunjukkan kalau korelasi tersebut signifikan. Hal ini mengindikasikan jika proporsi dewan komisaris independen mempengaruhi perilaku penghindaran pajak pada suatu perusahaan. Peran dewan komisaris independen yang diharapkan jalannya pengurusan dan kebijakan perseroan akan bersifat transparan, akuntabel, adil dan bertanggungjawab nyatanya tidak selalu efisien. Adanya korelasi positif yang signifikan menunjukkan bahwa semakin banyaknya proporsi dewan komisaris independen maka akan meningkatkan praktik penghindaran pajak, hal ini diduga karena faktor independensi dewan komisaris mampu untuk mempengaruhi tindakan penghindaran pajak yang dilakukan perusahaan. Hasil pengujian ini sejalan dengan penelitian yang dilakukan oleh Feranika (2016), Alviyani dkk. (2016) dan Putranti dan Setiawanta (2015) yang menemukan bahwa dewan komisaris independen berpengaruh positif terhadap perilaku tax avoidance.

Nilai probabilitas Koneksi Politik (KP) sebesar 0.2921> 0.05 dan coefficientnya sebesar 0.031103 artinya bahwa koneksi politik tidak berpengaruh terhadap tax avoidance. Tanda positif pada koefisien menggambarkan adanya korelasi positif antara koneksi politik terhadap tax avoidance. Hasil penelitian ini menunjukkan bahwa sekalipun perusahaan memiliki koneksi politik yang tercermin dari pemegang saham utama, dewan komisaris, komite audit ataupun dewan direksi yang memiliki jabatan atau peran penting di instansi pemerintah maupun partai politik namun, hal tersebut tidak dimanfaatkan oleh perusahaan untuk melakukan tindakan tax avoidance. Kedekatan dengan partai politik ataupun pemerintah memang memberikan beberapa keuntungan bagi perusahaan namun perusahaan harus memikirkan dampak jangka panjang yang akan ditimbulkannya. Buruknya citra perusahaan akan berdampak jangka panjang sehingga kepercayaan masyarakat akan menurun dan menyebabkan kerugian. Hal inilah yang menjadikan perusahaan yang memiliki koneksi politik justru lebih berhati-hati dalam pengambilan kebijakan atau keputusan perusahaan. Hasil ini mendukung penelitian yang dilakukan oleh Marfu'ah (2015), Murniyana (2018), Dharma dan Ardiana (2016) dan Lestari dan Putri (2017) yang menunjukkan bahwa koneksi politik tidak berpengaruh terhadap praktik penghindaran pajak.

Nilai probabilitas Profitabilitas (ROA) sebesar $0.0000<0.05$ dan coefficientnya sebesar -0.206975 artinya bahwa profitabilitas berpengaruh negatif terhadap tax avoidance. Tanda negatif pada koefisien menggambarkan adanya korelasi negatif antara profitabilitas terhadap tax avoidance, nilai probabilitas $<0.05$ menunjukkan hubungan yang signifikan. Hasil penelitian ini mengindikasikan bahwa ada pengaruh yang signifikan negatif antara profitabilitas terhadap tax avoidanceyang berarti semakin baik kemampuan perusahaan dalam menghasilkan laba bersih melalui total aktivanya maka akan menurunkan tingkat perilaku tax avoidance. Profitabilitas yang diukur dengan ROA merupakan salah satu indikator yang mencerminkan kinerja 
perusahaan, dimana semakin tinggi nilai ROA suatu perusahaan menunjukkan semakin baik kinerja perusahaan tersebut. Perusahaan yang mampu memperoleh laba bersih dan mengelola keuangannya dengan baik diasumsikan tidak akan melakukan tax avoidance karena mampu mengatur pendapatan dan pembayaran pajaknya (Maharani dan Suardana, 2014). Hasil pengujian ini sejalan dengan penelitian yang dilakukan oleh Maharani dan Suardana (2014) dan Agusti (2014) yang membuktikan bahwa profitabilitas yang diukur dengan rasio ROA (Return on Assets) memiliki pengaruh yang signifikan negatif terhadap tax avoidance.

\section{PENUTUP}

Kualitas audit tidak berpengaruh negatif terhadap tax avoidance. Hasil penelitian ini mengindikasikan jika tidak ada perbedaan antara perusahaan yang diaudit oleh KAP Big4 maupun perusahaan yang diaudit oleh KAP non Big 4 terhadap penanggulangan tindakan penghindaran pajak, hal ini karena KAP yang melakukan audit laporan keuangan pada suatu perusahaan berpedoman pada DSPAP IAPI (Dewan Standar Profesional Akuntan Publik Institut Akuntan Publik Indonesia).

Komite audit berpengaruh positif terhadap tax avoidance. Hasil penelitian ini menunjukkan bahwa adanya komite audit yang memiliki latar belakang akuntansi atau keuangan pada suatu perusahaan berpengaruh terhadap praktik tax avoidance. Hal ini dikarenakan anggota komite audit pada suatu perusahaan tidak menjalankan fungsinya dengan baik untuk meningkatkan integritas dan kredibilitas pelaporan keuangan perusahaan.

Dewan komisaris independen berpengaruh positif terhadap tax avoidance. Hal ini mengindikasikan jika proporsi dewan komisaris independen mempengaruhi perilaku penghindaran pajak pada suatu perusahaan. Peran dewan komisaris independen yang diharapkan jalannya pengurusan dan kebijakan perseroan akan bersifat transparan, akuntabel, adil dan bertanggung jawab nyatanya tidak selalu efisien. Adanya korelasi positif yang signifikan menunjukkan bahwa semakin banyaknya proporsi dewan komisaris independen maka akan meningkatkan praktik penghindaran pajak, hal ini diduga karena faktor independensi dewan komisaris mampu untuk mempengaruhi tindakan penghindaran pajak yang dilakukan perusahaan.

Koneksi politik tidak berpengaruh positif terhadap tax avoidance. Hasil penelitian ini menunjukkan bahwa sekalipun perusahaan memiliki koneksi politik yang tercermin dari pemegang saham utama, dewan komisaris, komite audit ataupun dewan direksi yang memiliki jabatan atau peran penting di instansi pemerintah maupun partai politik namun, hal tersebut tidak dimanfaatkan oleh perusahaan untuk melakukan tindakan tax avoidance. Kedekatan dengan partai politik ataupun pemerintah memang memberikan beberapa keuntungan bagi perusahaan namun perusahaan harus memikirkan dampak jangka panjang yang akan ditimbulkannya.

Return on asset berpengaruh negatif terhadap tax avoidance. Hasil penelitian ini mengindikasikan bahwa ada pengaruh yang signifikan negatif antara profitabilitas terhadap tax avoidance yang berarti semakin baik kemampuan perusahaan dalam menghasilkan laba bersih melalui total aktivanya maka akan menurunkan tingkat perilaku tax avoidance. Profitabilitas yang diukur dengan ROA merupakan salah satu indikator yang mencerminkan kinerja perusahaan, dimana semakin tinggi nilai ROA suatu perusahaan menunjukkan semakin baik kinerja perusahaan tersebut.

\section{REFERENSI}

Agusti, W. Y. (2014). Pengaruh Profitabilitas, Leverage dan Corporate Governance Terhadap Tax avoidance (Studi Empiris Pada Perusahaan Manufaktur yang Terdaftar di BEI tahun 2009-2012). Jurnal Akuntansi, 2 (3). 
Aminah, A., Chairina, C., \& Sari, Y. Y. (2018). The Influence of Company Size, Fixed Asset Intensity, Leverage, Profitability and Political Connection To Tax avoidance. AFEBI Accounting Review, 2 (02), 30-43.

Angruningrum, S., \& Wirakusuma, M. G. (2013). Pengaruh Profitabilitas, Leverage, Kompleksitas Operasi, Reputasi KAP dan Komite Audit Pada Audit Delay. E-Jurnal Akuntansi, 251-270.

Arviyanti \& Muiz, Enong. (2018). Pengaruh Karakteristik Perusahaan Dan Struktur Kepemilikan Terhadap Penghindaran Pajak/Tax avoidance Pada Perusahaan BUMN Yang Terdaftar Pada BEI Tahun 2013-2016. Jurnal Ekobis: Ekonomi Bisnis \& Manajemen Volume 7 Nomor 1. Sekolah Tinggi Ilmu Ekonomi Muhammadiyah Jakarta.

Boediono. (2002). Pedoman Umum Good Corporate Governance Indonesia. Jakarta: Komite Nasional Kebijakan Governance.

Butje, S., \& Tjondro, E. (2014). Pengaruh Karakter Eksekutif dan Koneksi Politik Terhadap Tax avoidance. Tax \& Accounting Review, 4 (2).

Chtourou, S. M., Bedard, J., \& Courteau, L. (2001). Corporate Governance and Earnings Management. Working Paper Universite Laval Quebec City Canada.

Darmawan, I. G. H., \& Sukartha, I. M. (2014). Pengaruh Penerapan Corporate Governance, Leverage, ROA, dan Ukuran Perusahaan Pada Penghindaran Pajak. E-Jurnal Akuntansi, 143-161.

Dewi, N. N. K., \& Jati, I. K. (2014). Pengaruh Karakter Eksekutif, Karakteristik Perusahaan dan Dimensi Tata Kelola Perusahaan yang Baik Pada Tax avoidance di Bursa Efek Indonesia. E-Jurnal Akuntansi, 249-260.

Dewinta, I. A. R., \& Setiawan, P. E. (2016). Pengaruh Ukuran Perusahaan, Umur Perusahaan, Profitabilitas, Leverage dan Pertumbuhan Penjualan Terhadap Tax avoidance. E-Jurnal Akuntansi, 1584-1615.

Dyreng, S. D., Hanlon, M., \& Maydew, E. L. (2009). The Effect of Executives on Corporate Tax avoidance. The Accounting Review, 85 (4) 1165-1189.

Faccio, M., Masulis, RW., \& McConnell, JJ. (2006). Political Connections and Corporate Bailouts. The Journal of Finance.

Fadhilah, R. (2014). Pengaruh Good Corporate Governance Terhadap Tax avoidance (Studi Empiris Pada Perusahaan Manufaktur yang Terdaftar di BEI 2009-2011. Jurnal Akuntansi, 2 (1).

Fadila, M., Rasuli, M., \& Rusli. (2017). Pengaruh Return on Assets, Leverage, Ukuran Perusahaan, Kompensasi Rugi Fiskal, Kepemilikan Institusional dan Koneksi Politik Terhadap Penghindaran Pajak. Jurnal Online Mahasiswa Fakultas Ekonomi Universitas Riau, 4 (1) 1671-1684.

Goldman, E., Rocholl J., \& So, J. (2009). Do Politically Connected Boards Affect Firm Value? The Review of Financial Studies, 22 (6) 2331-2360

Hanlon, M., \& Heitzman, S. (2010). A Review of Tax Research. Journal of Accounting and Economics , 50 (2-3) 127-178.

Hariyanto, L., \& Juniarti. (2014). Pengaruh Family Control, Firm Risk, Firm Size dan Firm Age Terhadap Profitabilitas dan Nilai Perusahaan Pada Sektor Keuangan. Business Accounting Review, 2 (1) 141-150.

Haruman. (2008). Pengaruh Struktur Kepemilikan Terhadap Keputusan Keuangan Dan Nilai Perusahaan Survey Pada Perusahaan Manufaktur Di PT. Bursa Efek Indonesia. Simposium Nasional Akuntansi XI, IAI dan FE Universitas Tanjung Pura.

Herusetya, A. (2009). Pengaruh Ukuran Auditor dan Spesialis Auditor Terhadap Kualitas Laba. Jurnal Akuntansi dan Keuangan Indonesia, 6 (1) 46-70.

Keputusan Menteri BUMN KEP-103/MBU/2002 Tanggal 04 Juni 2002. (2002, Juni). Retrieved Juni 2019, from Kementerian Badan Usaha Milik Negara Republik Indonesia: http://jdih.bumn.go.id 
Kurniasih, T., \& Sari, M. M. R. (2013). Pengaruh Return on Assets, Leverage, Corporate Governance, Ukuran Perusahaan dan Kompensasi Rugi Fiskal Pada Tax avoidance. Buletin Studi Ekonomi.

Laporan Keuangan Perusahaan Tercatat. (2016-2018). Retrieved Juni 2018, from Indonesia Stock Exchange: https://www.idx.co.id

Lestari, G. A. W., \& Putri, IGAM. A. D. (2017). Pengaruh Corporate Governance, Koneksi Politik, dan Leverage Terhadap Penghindara Pajak. E-Jurnal Akuntansi, 2028-2054.

Lim, Y. (2011). Tax avoidance, Cost of Debt and Shareholder Activism : Evidence From Korea. Journal of Banking \& Finance.

Lugesti, F. R. (2017). Pengaruh Penerapan Corporate Social Responsibility, Profitabilitas, Karakter Eksekutif dan Koneksi Politik Terhadap Penghindaran Pajak. Jurnal Online Universitas Muhammadiyah Surakarta.

Loderer, C., \& Waelchi, U. (2010). Firm Age and Performance. MPRA Paper No. 26450.

Maharani, I. G. A. C., \& Suardana, K. A. (2014). Pengaruh Corporate Governance, Profitabilitas dan Karakteristik Eksekutif Pada Tax avoidance Perusahaan Manufaktur. E-Jurnal Akuntansi, 525-539.

Mardiasmo, 2011. Perpajakan. Edisi Revisi. Penerbit ANDI. Yogyakarta

Maulana, \& Wati, L.N. (2019). Peran Koneksi Politik dan Struktur Kepemilikan dalam Peningkatan Nilai Perusahaan. Jurnal Akuntansi. Vol. 8 No. 1. Pp. 1-12.

Marfu'ah, L. (2015). Pengaruh Return on Assets, Leverage, Ukuran Perusahaan, Kompensasi Rugi Fiskal dan Koneksi Politik Terhadap Tax avoidance. Jurnal Akuntansi.

Memperbaiki Kinerja Tax Ratio: Sebuah Pendekatan Makro. (2018). from MHD. Ricky, K. L. Pegawai Direktorat Jenderal Pajak: http://pajak.go.id/id/artikel/memperbaiki-kinerja-taxratio-sebuah-pendekatan-makro

Mulyani, S. (2014). Pengaruh Karakteristik Perusahaan, Koneksi Politik dan Reformasi Perpajakan Terhadap Penghindaran Pajak. Jurnal Mahasiswa Perpajakan, 2 (1).

Munawaroh, M.A. \& Ramdany, Ramdany. (2019). Peran CSR, Ukuran Perusahaan, Karakter Eksekutif dan Koneksi Politik Terhadap Potensi Tax avoidance. Jurnal Akuntansi. Vol. 8 No. 2. Pp 109-121.

Murniyana, G. W. (2018). Pengaruh Koneksi Politik, Harga Transfer, Leverage dan Pertumbuhan Penjualan Terhadap Penghindaran Pajak (Studi Empiris Pada Perusahaan Manufaktur yang Listing di BEI Tahun 2015-2017). Jurnal Online Universitas Islam Indonesia.

Permata, A. D., Nurlaela, S. \& Endang, M. W. (2018). Pengaruh Size, Age, Profitability, Leverage dan Sales Growth Terhadap Tax avoidance. Jurnal Akuntansi dan Pajak, 19 (1) $10-20$.

Prastiwi, D. (2016). Pengaruh Corporate Governance dan Political Connection Terhadap Tax avoidance Pada Perusahaan yang Tercatat di BEI Tahun 2011-2015. Jurnal Akuntansi Fakultas Ekonomi Universitas Negeri Surabaya.

Scott, W. R. 2000. Financial Accounting Theory. 2nd edition. Canada: Prentice Hall.

Sudarmadji, A. M., \& Sularto, L. (2007). Pengaruh Ukuran Perusahaan, Profitabilitas, Leverage dan Tipe Kepemilikan Perusahaan Terhadap Luas Voluntary Disclosure Laporan Keuangan Tahunan. Seminar Ilmiah Nasional PESAT.

Swingly, C., \& Sukartha, I, M. (2015). Pengaruh Karakter Eksekutif, Komite Audit, Ukuran Perusahaan, Leverage dan Sales Growh Pada Tax avoidance. E-Jurnal Akuntansi, 47-62.

Triwahyuningtias, M., \& Muharam, H. (2012). Analisis Pengaruh Struktur Kepemilikan, Ukuran Dewan Komisaris Independen, Likuiditas dan Leverage Terhadap Terjadinya Kondisi Financial Distress . Jurnal Online Fakultas Ekonomika dan Bisnis Universitas Diponegoro.

Utari, N. K. Y., \& Supadmi, N. L. (2017). Pengaruh Corporate Governance, Profitabilitas dan Koneksi Politik Pada Tax avoidance. E-Jurnal Akuntansi, 2202-2230.

Sari, R. P. (2010). Pengaruh Komite Audit Terhadap Kinerja Keuangan (Studi Empiris pada Perusahaan Property dan Real Estate di Bursa Efek Indonesia 2005-2008). 
Waluyo, T. M., \& Basri, Y. M. (2014). Pengaruh Return on Assets, Leverage, Ukuran Perusahaan, Kompensasi Rugi Fiskal dan Kepemilikan Institusi Terhadap Penghindaran Pajak. Jurnal Akuntansi.

Wardhani, R. (2006). Mekanisme Corporate Governance Dalam Perusahaan yang Mengalami Permasalahan Keuangan (Financially Distressed Firm). Simposium Nasional Akuntansi, 9 1-26.

Wati, L.N., Primiana, I. and Sudarsono, R. 2016. Political connections of conglomerates: evidence from Indonesia Stock Exchange. Actual Problems of Economics. (12), pp.110119.

Wati,L.N. (2017). Metodologi Penelitian Bisnis Terapan, Aplikasi SPSS, EVIEWS, SmartPLS, dan AMOS. Bandung: Mujahid Press.

Wati, L. N. (2017). Board of commissioner's effectiveness on politically connected conglomerates: Evidence from Indonesia. Pertanika Journal Social Sciences \& Humanities, 25(S), pp. 255-270.

Wati, L. N.; Primiana, H. I.; Pirzada, K.; Sudarsono, R. 2019. Political connection, block holder ownership and performance, Entrepreneurship and Sustainability Issues 7(1): 52-68.

Watkins, A. L., Hillison, W., \& Morecroft, S. E. (2004). Audit Quality : A Synthesis of Theory and Empirical Evidence. Journal of Accounting Literature No. 23, 153-193.

Winata, F. (2015). Pengaruh Corporate Governance Terhadap Tax avoidance Pada Perusahaan yang Terdaftar di Bursa Efek Indonesia Tahun 2013. Tax \& Accounting Review, 4 (1) 162.

Zain, M. (2008). Manajemen Perpajakan. Jakarta: Salemba Empat. Edisi 3. 